\title{
A NEW SPECIES OF AZYA MULSANT FROM BRAZIL (COLEOPTERA, COCCINELLIDAE) FEEDING ON PULVINARIA PARANAENSIS HEMPEL (HOMOPTERA, COCCIDAE) ON ILEX PARAGUARIENSIS ST.HIL. (AQUIFOLIACEAE) ${ }^{1}$
}

\author{
Lúcia Massutti de Almeida ${ }^{2}$ \\ Regina Célia Zonta de Carvalho ${ }^{3}$
}

\begin{abstract}
Azya ilicis sp.n. from Brazil, is described. The new taxon is integrated into the most recent key to species.

KEY WORDS. Coleoptera, Coccinellidae, Azya, Homoptera, Coccidae, new species
\end{abstract}

The genus Azya Mulsant contains thirteen Neotropical species. Most of them are of potential importance for biological control and have been introduced to other regions of the world. A new species from Bituruna and Cruz Machado, Paraná State, Brazil, was found feeding voraciously on Pulvinaria paranaensis Hempel, 1929 from Ilex paraguariensis St.Hil., an important crop in southern Brazil. Gordon (1980) listed several scales as hosts of Azya, but Pulvinaria paranaensis Hempel is here recorded for the first time. In this paper the newest member of the genus is described and a detailed morphological study of the male and female genitalia is presented and illustrated. The new taxon is integrated into Gordon's key to species.

The following acronyms are used for the institutes where the material is deposited: (DZUP) Coleção de Entomologia Pe. J.S. Moure, Departamento de Zoologia, Universidade Federal do Paraná, Curitiba, Paraná, Brazil; (MZSP) Museu de Zoologia, Universidade de São Paulo, São Paulo, São Paulo, Brazil.

\section{Azya ilicis sp.n.}

Figs 1-4

Holotype. Male, length $3.33 \mathrm{~mm}$, width $3.00 \mathrm{~mm}$. Form oval. Dorsal surface black, clothed with dense, semi-decumbent white and short pubescence, with a large discal spot composed of black hairs, not reaching humeral callus and extending a little beyond the mid-length of elytron (Fig. 1). Venter black except mouths parts, legs and abdomen yellow. Abdomen with postcoxal lines incomplete, extending downwards almost to hind margin of 1st sternum. Genitalia with basal lobe shorter

1) Contribution no. 943 of Departamento de Zoologia, Universidade Federal do Paraná.

2) Departamento de Zoologia, Universidade Federal do Paraná. Caixa Postal 19020, 81531-990 Curitiba, Paraná, Brazil.

3) Secretaria de Estado da Agricultura e do Abastecimento do Paraná, Centro de Diagnóstico Marcos Enrietti. Rua Jaime Balão 575, 80040-340 Curitiba, Paraná, Brazil. 


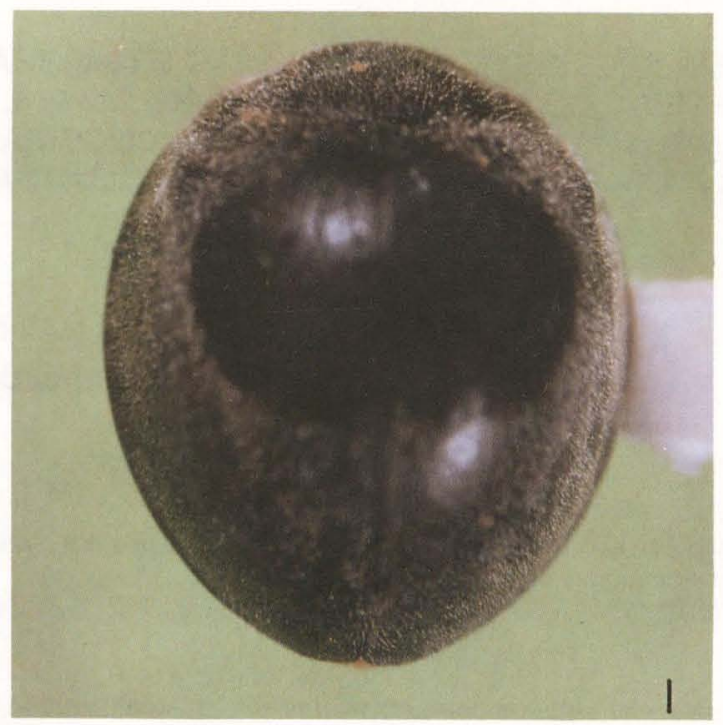

Fig. 1. Azya ilicis sp.n. Holotype.
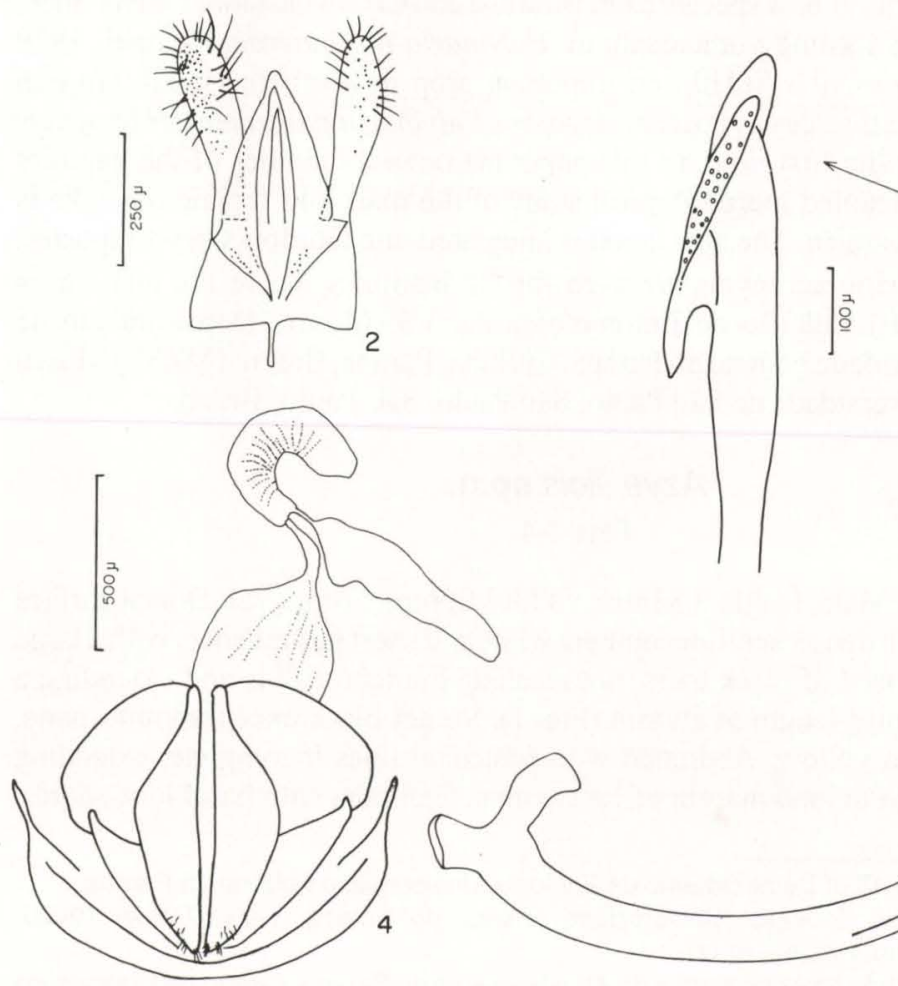

Figs 2-4. Azya ilicis sp.n.. (2) Basal lobe; (3) sipho; (4) female genitalia.

Revta bras. Zool. 13 (3): 643 - 645, 1996 
than paramere, broad at base, abruptly narrowing at apex, paramere narrow at base with short pubescence (Fig. 2); apex of sipho with a ventral flap before apex (Fig. $3)$.

Female. Similar to male. Genitalia with apex of spermathecal capsule broader than base; genital plate elongate, triangular (Fig. 4).

Type material. Holotype male, BRAZIL, Paraná: Bituruna, 2-XII-1992, Klobukoski leg. (DZUP). Paratypes, same data as holotype: 3 males, 2 females (DZUP); 2 males, 1 female (MZSP). Cruz Machado, 2 males, 3 females, 27-XI1991, Kocekoski leg. (DZUP); 1 male, 2 females (MZSP).

Variation. Length $2.92 \mathrm{~mm}$ to $3.58 \mathrm{~mm}$; width $2.58 \mathrm{~mm}$ to $3.33 \mathrm{~mm}$.

Remarks. This species is similar in appearance to A. scutata Mulsant, 1850 but in A. ilicis the discal spot only extends a little beyond the mid-length of elytron; the basal lobe is broad at base; the apex of paramere is broad, and the apex of sipho has a large flap at base. In $A$. scutata the discal spot extends over $2 / 3$ of the elytral length; the basal lobe is thin; the apex of paramere is equal to the basal width, and the sipho has a thickened area near apex.

The key to species of Azya in GoRDON (1980) should be modified as follow to include the new species:

10. Elytron with coarse punctures intermixed with fine punctures on disc; body narrowed apically; Peru ......................... satipoi - Elytron without coarse punctures on disc; body round $\ldots \ldots \ldots \ldots \ldots \ldots 11$ 11. Elytral spot extending over $2 / 3$ of the elytral length ............ scutata - Elytral spot extending only a little beyond middle of elytral length ... ilicis sp.n. 12. Dorsum covered with brown pubescence, appearing glabrous ........ exuta - Dorsum covered with dense, white pubescence ................ 13

13. Dorsal pubescence long; Mexico ................... mexicana - Dorsal pubescence short; Colombia ................. murillo

\section{REFERENCES}

Gordon, R.D. 1980. The tribe Azyini (Coleoptera: Coccinellidae): historical review and taxonomic revision. Trans. Amer. Ent. Soc. 106: 149-203.

Recebido em 09.V.1996; aceito em 18.XI.1996 